\title{
BRAZIL AND SLAVERY
}

African Heritage and Memories of Slawery in Brazil and the South Atlantic World. By Ana Lucia Araujo. Amherst: Cambria Press, 2015. Pp. 406. \$124.99 cloth. doi:10.1017/tam.2018.65

This new collection of essays, edited by historian Ana Lucia Araujo, addresses an important and timely topic. The book brings together ten chapters from renowned Brazilian and international scholars who explore the heritage of slavery and of African heritage in Brazil. The volume begins with a concise yet instructive introduction by Araujo, presenting an overview of how the Atlantic slavery past has come to be (under) appreciated in Brazilian society in post-abolition times. Araujo highlights the contemporary reemergence of a public debate in Brazil about the importance of valorizing and commemorating the country's slavery past and its African heritage.

Effectively connected to each other, the ten chapters are organized in chronological order and together present a well-rounded selection of examples of the memory and heritage of slavery and enslaved peoples, analyzing them from the perspectives of material culture and museology, visual culture and performance studies, popular culture, archaeological heritage, memory and oral history, tourism, and historiography. Some chapters are very informative and document recent developments in the memorialization of slavery and heritage practices. This is the case for Cicalo's important essay about the Valongo Wharf in Rio de Janeiro, which will serve as a solid starting point for further reflections on the development of slavery memorialization sites in post-abolition societies. The listing of the Valongo Wharf as a World Heritage Site by UNESCO in 2017 attests to the importance of the subject matter and the relevance of this publication.

Likewise, Cleveland's chapter on the Museu Afro-Brasil describes and analyzes this museum's permanent display and how it challenges traditional (mis)perceptions about Brazil's African heritage. Both chapters examine recent initiatives in the Brazilian cultural arena that have the potential to push forward a more inclusive, democratic, and fact-based agenda in the Brazilian public debate. In the same manner, the chapter by Abreu and Mattos documents, in a compelling and transparent writing style, the process through which these two scholars discovered and rediscovered the jongo, the calango, and the folia de reis popular festivals as both social practices and subjects of research and political engagement.

Other chapters propose new or expanded lines of research that can inspire scholars of slavery and African heritage in Brazil. Such is the case for the chapters by Soares, Machado, and Schenk and Candido. Soares investigates the Africana collection at the Museu Nacional in Rio de Janeiro, a relatively small yet rich collection that showcases the continuing history of Brazilian-African political, diplomatic, and cultural 
relationships. She also suggests ways in which a number of important pieces can be used for educational purposes and the dissemination of knowledge about Brazil's slavery and African past. We can hope that more studies of specific objects and collection will follow, by this and other scholars.

Machado's essay focuses on a set of about 200 photographs of African Brazilians by Louis Agassiz, housed at the Peabody Museum of Archaeology and Ethnology at Harvard. These mid nineteenth-century photographs, taken in the context of the Thayer expedition to Brazil, were intended to be a visual archive that would allow for racial comparisons. Ultimately, they also helped to shape modern ideals of beauty. The chapter also points to the existence of more such racialized and eroticized photographs (also of Brazilian indigenous peoples) at the Harvard museum; these will merit further study. Focusing on the other side of the Atlantic, the chapter by Schenk and Candido shows the research potential of connecting the archival historiography of slavery with oral history. Although the oral history approach is not new, the use of such research techniques for the case of Angola's slavery past is original and promises to bring to light a multitude of still unanswered questions about how Angolan people perceive and deal with the heritage of slavery in present times.

The last chapter, by Santos, sums up the sociological conditions in which the difficult legacy of slavery was and is understood, experienced, and represented in Brazilian historiography and society, thereby providing a logical concluding reflection for this important volume. The book will be of interest and use to scholars of slavery, history, anthropology, and heritage studies, and it should be praised for making a number of relevant topics in Brazilian history accessible to the English-speaking public.

Leiden University

Mariana C. FrançOZO

Leiden, Netherlands

m.de.campos.francozo@arch.leidenuniv.nl

\section{BRITISH CARIBBEAN AND SLAVERY}

Surviving Slavery in the British Caribbean. By Randy M. Browne. Philadelphia: University of Pennsylvania Press, 2017. Pp. 279. $\$ 45.00$ cloth.

doi:10.1017/tam.2018.66

This book is incontestable proof: despite growth in the scholarship on Caribbean slavery, there are yet-untapped sources and approaches on the subject still awaiting the scrutiny of the diligent historian.

The first and most obvious strength of the publication is the solidity of its sources. It is shaped by an incisive interrogation of primary documents, chief among which are records that fiscals and protectors of the enslaved in Berbice created in the last years of 